\title{
Profil Konsep Diri Terhadap Motivasi Belajar Siswa
}

\author{
Lucky Adelia Apriani ${ }^{1 *}$, Eka Sari Setianingsih², Joko Sulianto ${ }^{3}$ (iD \\ 1,2,3 Jurusan PGSD Fakultas Ilmu Pendidikan Universitas PGRI Semarang, Indonesia \\ *Corresponding author: helendras@yahoo.com
}

\begin{abstract}
Abstrak
Masih terdapat siswa yang kurang mengetahui pentingnya konsep perkembangan diri, kurangnya disiplin dalam belajar, disiplin masuk kelas dan disiplin mengerjakan tugas. Permasalahan lain yaitu siswa kurang menghargai waktu dalam mengerjakan tugas dan juga masuk kelas. Tujuan penelutian ini menganalisis profil konsep diri terhadap motivasi belajar siswa kelas V sekolah dasar. Jenis penelitian ini adalah penelitian kualitatif, menggunakan metode observasi, wawancara, angket, dan dokumentasi. Analisis data dapat dilakukan dengan cara pengumpulan data (data collection), penyajian data (data display), reduksi data (data reduction), verifikasi penarikan kesimpulan (conclusion drawing/verification. Penelitian melakukan pengumpulan data berupa hasil pengamatan penelitian selama melakukan penelitian seperti hasil wawancara dengan guru, kepala sekolah dan siswa. Hasil penelitian menunjukkan pengembangan konsep diri sudah diterapkan melalui kegiatan pembiasaan. Siswa dilatih untuk dapat mengembangkan konsep perkembangan diri dalam setiap kegiatan pembelajaran berlangsung untuk pembentukan karakter siswa. Hal ini sangatlah penting untuk siswa dapat mengembangkan diri sehingga dapat mencapai tujuan pembelajaran. Berdasarkan hasil penelitian, dapat disimpulkan bahwa konsep diri berpengaruh terhadap motivasi belajar siswa.
\end{abstract}

Kata kunci: Konsep Diri, Motivasi Belajar

\section{Abstract}

There are still students who do not know the importance of the concept of self-development, lack of discipline in learning, discipline in going to class, and discipline in doing assignments. Another problem is that students do not appreciate time in doing assignments and also attending class. The purpose of this research is to analyze the profile of self-concept on the learning motivation of fifth-grade elementary school students. This type of research is qualitative research, using the methods of observation, interviews, questionnaires, and documentation. Data analysis can be done by collecting data (data collection), data presentation (data display), data reduction (data reduction), verification of conclusion drawing (conclusion drawing/verification. Research collects data in the form of research observations during research such as the results of interviews). with teachers, principals, and students. The results show that self-concept development has been implemented through habituation activities. Students are trained to be able to develop the concept of self-development in every learning activity that takes place for the formation of student character. This is very important for students to develop self so that it can achieve learning objectives. Based on the results of the study, it can be concluded that self-concept affects students' learning motivation.

\section{INTRODUCTION}

Konsep diri merupakan salah satu aspek perkembangan psikososial peserta didik yang penting dipahami oleh seorang guru. Hal ini karena konsep diri merupakan salah satu variabel yang menentukan dalam proses pendidikan. Penyebab bukti yang menguatkan bahwa rendahnya prestasi dan motivasi belajar siswa serta terjadinya penyimpangan penyimpangan perilaku siswa di kelas banyak disebabkan oleh persepsi dan sikap negatif siswa terhadap diri sendiri (Budiarnawan et al., 2014; Jatmiko, 2017; Magfirah et al., 2015). Demikian juga dengan siswa yang mengalami kesulitan belajar, lebih disebabkan oleh sikap siswa yang memandang dirinya tidak mampu melaksanakan tugas-tugas di sekolah. Maka diperlukan konsep diri dan motivasi yang kuat dalam diri siswa. Motivasi dapat dirangsang oleh faktor dari luar, tetapi motivasi itu tumbuh di dalam diri seseorang. Lingkungan merupakan salah faktor dari luar yang dapat menumbuhkan motivasi dalam diri seseorang untuk belajar (Handhika, 2012; Sunarti et al., 2016).Namun, permasalahan yang terjadi di

$\begin{array}{lll}\text { History: } & & \text { Publisher: Undiksha Press } \\ \text { Received } & : 20 \text { November } 2020 & \text { Licensed: This work is licensed under } \\ \text { Revised } & : 11 \text { Desember } 2020 & \text { a Creative Commons Attribution 3.0 License } \\ \text { Accepted } & : 26 \text { April } 2021 & \text { CC } \\ \text { Published } & : 25 \text { Mei } 2021 & \text { (C) }\end{array}$


SDN Mangunharjo yaitu masih rendah kepeduliannya siswa terhadap keadaan sekitar. Hal itu tercermin dari rendahnya kepedulian siswa kelas V kepada guru yang menyampaikan materi. Beberapa siswa takut memberikan menjawab pertanyaan dari guru karena takut salah menjawab. Masih terdapat beberapa siswa lebih memilih mencontek pekerjaan rumah dengan teman yang dianggapnya lebih pintar. Terdapat siswa yang saling megejek fisik temannya dan masih ada siswa yang tidak percaya diri dengan kondisi diri sendiri.

Motivasi belajar adalah dorongan internal dan eksternal pada siswa-siswa yang sedang belajar untuk mengadakan perubahan tingkah laku pada umumnya, dengan beberapa indikator motivasi belajar yaitu 1) adanya hasrat dan keinginan berhasil, (2) adanya dorongan dan kebutuhan dalam belajar, 3) adanya harapan dan cita-cita masa depan, (4) adanya penghargaan dalam belajar, (5) adanya kegiatan yang menarik dalam belajar, dan (6) adanya lingkungan belajar yang kondusif, sehingga memungkinkan seseorang siswa dapat belajar dengan baik. Ciri-ciri seseorang yang memiliki motivasi belajar yaitu (1) memperlihatkan minat dan perhatian yang serius terhadap apa yang dipelajari; (2) memiliki orientasi masa depan; (3) cenderung mengerjakan tugas-tugas belajar yang menantang, tetapi tidak berada di luar batas kemampuannya; (4) memiliki keinginan yang kuat untuk terus berkembang; (5) selalu menyediakan waktu untuk belajar; (6) tekun belajar dan cenderung berupaya menyelesaikan tugas yang diberikan kepadanya (Abrianto, 2019; Nasrah \& Muafiah, 2020; Widiastiti \& Sumantri, 2020). Motivasi belajar yang timbul pada siswa tergantung derajat motivasi belajar yang dimilikinya, ini dapat mengacu pada faktor internal dan eksternal maupun situasional sebagaimana pengertian motivasi itu sendiri yang merupakan inner drive (Putri \& Isnani, 2019; Sa'diyah, 2020; Waluya et al., 2019). Untuk membentuk motivasi belajar yang lebih kuat, maka harus ada stimulus dari luar atau faktor eksternal yang dapat memacu siswa dalam mencapai kesuksesan, dalam hal ini diantaranya konsep diri dan kecerdasan emosional.

Konsep diri merujuk pada bagaimana individu memahami dirinya sebagai pribadi jika dihadapkan dengan tugas-tugas perkembangannya, dalam kaitannya dengan pelaksanaan tugas sesuai tuntutan pribadi yang dihadapkan dengan tuntutan lingkungan dalam upaya mengoptimalkan potensinya (Agustini \& Agustika, 2020; Asy'ari et al., 2014; Lestari et al., 2018). Konsep diri yang positif memberikan gambaran adanya kepercayaan diri yang tinggi dalam sesuatu untuk mencapai motivasi belajar dan hasil belajar maksimal, dan sebaliknya konsep diri siswa negatif sudah tentu akan menimbulkan rasa rendah diri yang pada akhirnya mudah putus asa (Juniarti et al., 2020; Setiadewi et al., 2019). Konsep diri yang positif memberikan gambaran adanya kepercayaan diri yang tinggi dalam sesuatu untuk mencapai hasil belajar maksimal. Sebaliknya konsep diri siswa negatif sudah tentu akan menimbulkan rasa rendah diri yang pada akhirnya mudah putus asa. Konsep diri merupakan penentu sikap seseorang dalam bertingkah laku, artinya apabila seseorang cenderung berpikir akan berhasil, maka hal ini merupakan kekuatan atau dorongan yang akan membuat seseorang menuju kesuksesan. Sebaliknya jika seseorang berpikir akan gagal, maka hal ini sama saja mempersiapkan kegagalan bagi dirinya.

Beberapa penelitian yang relevan dengan penelitian ini dilakukan oleh (Lestari et al., 2018) yang menemukan bahwa terdapat hubungan yang positif antara konsep diri dan motivasi berprestasi dengan hasil belajar IPS siswa. Kemudian penelitian lain juga menemukan bahwa terdapat hubungan yang positif dan signifikan antara pola asuh orang tua dan konsep diri dengan kompetensi pengetahuan matematika siswa kelas V (Juniarti et al., 2020). Penelitian lain juga menemukan bahwa ada hubungan positif yang signifikan antara konsep diri dengan motivasi belajar siswa (Asy'ari et al., 2014). Tujuan penelutian ini menganalisis profil konsep diri terhadap motivasi belajar siswa kelas V sekolah dasar.. 


\section{MATERIALS AND METHODS}

Penelitian ini merupakan penelitian kualitatif. Penelitian ini dilaksanakan SDN Mangunharjo untuk mengetahui profil konsep diri terhadap motivasi belajar siswa kelas V. Data dikumpulkan menggunakan teknik wawancara, pengamatan, dan pengumpulan dokumentasi. Instrumen penelitian yang digunakan dalam penelitian ini adalah pedoman wawancara, observasi, angket, serta dokumentasi untuk pengumpulan data. Indikator penyusunan yang metiputi aspek psikologis, aspek psiko-sosiologis, aspek spiritual dan aspek moral, yang di bagikan kepada siswa kelas V SDN Mangunharjo. Wawancara yang dilakukan dengan Kepala sekolah dan guru tentang konsep diri siswa kelas V SDN Mangunharjo. Dokumentasi foto diambil pada saat pelaksanaan penelitian tentang hubungan konsep diri terhadap motivasi belajar siswa. Angket diberikan pada siswa yang berisi beberapa pernyataan terkait dengan kondisi siswa yang terkait dengan konsep diri dan motivasi belajar.

Peneliti melakukan pengecekan keabsahan data dengan menggunakan teknik peningkatan ketekunan, triangulasi, menggunakan bahan referensi. Salah satu pengecekan keabsahan data dalam penelitian ini melalui triangulasi sumber yaitu diambil dari sumber wawancara yang dilakukan pada guru dan kepala sekolah. Bahan referensi yang digunakan adalah script hasil wawancara dengan kepala sekolah dan guru, script hasil observasi dan script hasil angket siswa. Dokumentasi foto dan video saat pelaksanaan Gerakan Literasi Sekolah. Analisis data dapat dilakukan dengan cara pengumpulan data (data collection), penyajian data (data display), reduksi data (data reduction), verifikasi penarikan kesimpulan (conclusion drawing/verification. Penelitian melakukan pengumpulan data berupa hasil pengamatan penelitian selama melakukan penelitian seperti hasil wawancara dengan guru, kepala sekolah dan siswa. Mereduksi data dengan memilik dan merangkum hal pokok dari wawancara, angket dan observasi yang berkaitan dengan konsep diri dan motivasi belajar siswa. Penyajian data disajikan dalam teks naratif. Kesimpulan didapatkan setelah mereduksi data yang telah disajikan melalui teks naratif yang berasal dari hasil wawancara dengan kepala sekolah dan guru, hasil angket dan observasi prilaku siswa

\section{RESULTS AND DISCUSSION}

Hasil yang didapatkan melalui wawancara, observasi dan angket. Pada observasi yang dilakukan yaitu mengamati siswa saat melakukan pembelajaran dengan guru. Setelah pembelajaran dengan guru peneliti membagikan angket kepada siswa, dan siswa dipersilahkan untuk mengisi angket yang telah dibagikan. Setelah itu peneliti mewawancarai siswa kelas V. Wawancara yang dilakukan dengan guru dan kepala sekolah didapatkan hasil perkembangan konsep diri siswa menjadi lebih baik terlihat dari kegiatan spiritual seperti berdoa sebelum dan sesudah pembelajaran. Adanya sikap menghormati kepada guru terlihat menyapa guru ketika bertemu. Berdasarkan hasil angket, diketahui bahwa 3 siswa berada pada kategori sangat tinggi pada konsep diri, kemudian 16 siswa pada kategori tinggi, 1 siswa pada kategori cukup kurang. Rata-rata hasil angket konsep diri siswa diperoleh termasuk kategori tinggi.

Konsep diri siswa dikembangkan melalui kegiatan-kegiatan pembiasaan. Siswa dilatih untuk mengembangkan konsep diri melalui kegiatan pembelajaran yang bertujuan untuk pembentukan karakter siswa. Hal ini sangatlah penting uuntuk siswa dapat mengembangkan diri dengan baik. Perkembangan konsep diri itu berpengaruh dengan lingkungan di dalam kelas yakni terhadap perkembangan karakter anak (Budiariawan, 2019; Sari et al., 2020). Adanya kerja sama yang baik antara siswa dan adanya sikap toleransi. Konsep diri merujuk pada bagaimana individu memahami dirinya sebagai pribadi jika dihadapkan dengan tugastugas perkembangannya, dalam kaitannya dengan pelaksanaan tugas sesuai tuntutan pribadi yang dihadapkan dengan tuntutan lingkungan dalam upaya mengoptimalkan potensinya. 
Konsep diri yang positif memberikan gambaran adanya kepercayaan diri yang tinggi dalam sesuatu untuk mencapai motivasi belajar dan hasil belajar maksimal. Sebaliknya konsep diri siswa negatif sudah tentu akan menimbulkan rasa rendah diri yang pada akhirnya mudah putus asa. Konsep diri yang positif memberikan gambaran adanya kepercayaan diri yang tinggi dalam sesuatu untuk mencapai hasil belajar maksimal. Sebaliknya konsep diri siswa negatif sudah tentu akan menimbulkan rasa rendah diri yang pada akhirnya mudah putus asa. Konsep diri merupakan penentu sikap seseorang dalam bertingkah laku, artinya apabila seseorang cenderung berpikir akan berhasil, maka hal ini merupakan kekuatan atau dorongan yang akan membuat seseorang menuju kesuksesan. Sebaliknya jika seseorang berpikir akan gagal, maka hal ini sama saja mempersiapkan kegagalan bagi dirinya. Konsep diri ini akan berkaitan pula dengan motivasi belajar siswa.

Konsep diri adalah konsep seseorang dari siapa dan apa dia itu. Konsep ini merupakan bayangan cermin, ditentukan sebagian besar oleh peran dan hubungan dengan orang lain, dan apa yang kiranya reaksi orang lain terhadapnya.Konsep diri mempunyai peranan penting dalam menentukan tingkah laku seseorang. Bagaimana seseorang memandang dirinya akan tercermin dari keseluruhan perilakunya. Konsep diri mencakup citra diri fisik dan psikologis. Citra diri fisik biasanya berkaitan dengan penampilan, sedangkan citra diri psikologis berdasarkan atas pikiran, perasaan, dan emosi (Budiariawan, 2019; Yusuf et al., 2021). Apabila seseorang telah mempunyai konsep diri tertentu, ia akan memandang dirinya sesuai konsep dirinya. Jika memiliki konsep diri yang baik, ia akan meyakini bahwa dirinya sebagai orang yang berkpribadian baik dan tingkah lakunya disesuaikan dengan sebutan dirinya. Dengan demikian, konsep diri merupakan aspek penting dalam diri seseorang, karena konsep diri seseorang merupakan kerangka acuan dalam berinteraksi dengan lingkungannya.

Motivasi belajar adalah dorongan internal dan eksternal pada siswa-siswa yang sedang belajar untuk mengadakan perubahan tingkah laku pada umumnya, dengan beberapa indikator motivasi belajar yaitu 1) adanya hasrat dan keinginan berhasil, (2) adanya dorongan dan kebutuhan dalam belajar, 3) adanya harapan dan cita-cita masa depan, (4) adanya penghargaan dalam belajar, (5) adanya kegiatan yang menarik dalam belajar, dan (6) adanya lingkungan belajar yang kondusif, sehingga memungkinkan seseorang siswa dapat belajar dengan baik. Ciri-ciri seseorang yang memiliki motivasi belajar yaitu (1) memperlihatkan minat dan perhatian yang serius terhadap apa yang dipelajari; (2) memiliki orientasi masa depan; (3) cenderung mengerjakan tugas-tugas belajar yang menantang, tetapi tidak berada di luar batas kemampuannya; (4) memiliki keinginan yang kuat untuk terus berkembang; (5) selalu menyediakan waktu untuk belajar; (6) tekun belajar dan cenderung berupaya menyelesaikan tugas yang diberikan kepadanya (Abrianto, 2019; Nasrah \& Muafiah, 2020; Widiastiti \& Sumantri, 2020). Motivasi belajar yang timbul pada siswa tergantung derajat motivasi belajar yang dimilikinya, ini dapat mengacu pada faktor internal dan eksternal maupun situasional sebagaimana pengertian motivasi itu sendiri yang merupakan inner drive (Putri \& Isnani, 2019; Sa'diyah, 2020; Waluya et al., 2019). Untuk membentuk motivasi belajar yang lebih kuat, maka harus ada stimulus dari luar atau faktor eksternal yang dapat memacu siswa dalam mencapai kesuksesan, dalam hal ini diantaranya konsep diri dan kecerdasan emosional mencapai kesuksesan, dalam hal ini diantaranya konsep diri dan kecerdasan emosional (Darmawati, 2017; Suminah et al., 2019).

Beberapa penelitian yang relevan dengan penelitian ini dilakukan oleh (Lestari et al., 2018) yang menemukan bahwa terdapat hubungan yang positif antara konsep diri dan motivasi berprestasi dengan hasil belajar IPS siswa. Kemudian penelitian lain juga menemukan bahwa terdapat hubungan yang positif dan signifikan antara pola asuh orang tua dan konsep diri dengan kompetensi pengetahuan matematika siswa kelas V (Juniarti et al., 2020). Penelitian lain juga menemukan bahwa ada hubungan positif yang signifikan antara konsep diri dengan motivasi belajar siswa (Asy’ari et al., 2014). 


\section{CONCLUSION}

Konsep diri berpengaruh terhadap motivasi belajar siswa. Pengembangan konsep diri sudah diterapkan di SD N Mangunharjo melalui kegiatan pembiasaan. Siswa dilatih untuk dapat mengembangkan konsep perkembangan diri dalam setiap kegiatan pembelajaran berlangsung untuk pembentukan karakter siswa. Hal ini sangatlah penting untuk siswa dapat mengembangkan diri sehingga dapat mencapai tujuan pembelajaran.

\section{REFERENCES}

Abrianto, O. R. (2019). Penerapan Metode Tutor Sebaya Untuk Meningkatkan Hasil Belajar Dan Motivasi Belajar Siswa Pada Materi Trigonometri Kelas XI Mipa 4 SMA Negeri 1 Ambarawa. Satya Widya, 35(1), 62-74. https://doi.org/10.24246/j.sw.2019.v35.i1.p62-74.

Agustini, N. K. A., \& Agustika, G. N. S. (2020). Kontribusi Konsep Diri dan Motivasi Belajar Terhadap Kompetensi Pengetahuan Matematika. Mimbar PGSD Undiksha, 8(1), 70-79. http://dx.doi.org/10.23887/jjpgsd.v8i1.24580.

Asy'ari, M., Ekayati, I. N., \& Matulessy, A. (2014). Konsep Diri, Kecerdasan Emosi dan Motivasi Belajar Siswa. Persona:Jurnal Psikologi Indonesia, 3(01). https://doi.org/10.30996/persona.v3i01.372.

Budiariawan, I. P. (2019). Hubungan Motivasi Belajar Dengan Hasil Belajar Pada Mata Pelajaran Kimia. Jurnal Pendidikan Kimia Indonesia, 3(2), 103. https://doi.org/10.23887/jpk.v3i2.21242.

Budiarnawan, K. A., Antari, N. N. M., \& Rati, N. W. (2014). Hubungan Antara Konsep Diri Dan Pola Asuh Orang Tua Terhadap Hasil Belajar Ipa Siswa Kelas V Sd Di Desa Selat. Mimbar PGSD Undiksha, 2(1). http://dx.doi.org/10.23887/jjpgsd.v2i1.2224.

Darmawati, J. (2017). Pengaruh Motivasi Belajar Dan Gaya Belajar Terhadap Prestasi Belajar Ekonomi Siswa Sma Negeri Di Kota Tuban. Jurnal Ekonomi Pendidikan Dan Kewirausahaan, 1(1), 79. https://doi.org/10.26740/jepk.v1n1.p79-90.

Handhika, J. (2012). Efektivitas media pembelajaran im3 ditinjau dari motivasi belajar. Jurnal Pendidikan IPA Indonesia, I(2), 109-114. https://doi.org/10.15294/jpii.v1i2.2127.

Jatmiko, A. (2017). Pengaruh Model Pembelajaran Dan Konsep Diri Terhadap Hasil Belajar IPA. Biosfer Jurnal Tadris Pendidikan Biologi, 8(2), 84-101. https://doi.org/10.24042/biosf.v8i2.2300.

Juniarti, N. K. R., Margunayasa, I. G., \& Kusmariyatni, N. (2020). Hubungan Antara Pola Asuh Orang Tua dan Konsep Diri dengan Kompetensi Pengetahuan Matematika $\begin{array}{lllll}\text { Siswa. Jurnal Ilmiah Sekolah } & 17 .\end{array}$ https://doi.org/10.23887/jisd.v4i1.24273.

Lestari, A., Solihatin, E., \& Sudrajat, A. (2018). Hubungan Konsep Diri Dan Motivasi Berprestasi Siswa Dengan Hasil Belajar Ilmu Pengetahuan Sosial. Jurnal Tunas Bangsa, 5(2), 175-183. https://ejournal.bbg.ac.id/tunasbangsa/article/view/944.

Magfirah, I., Rahman, U., \& Sulasteri, S. (2015). Pengaruh Konsep Diri Dan Kebiasaan Belajar Terhadap Hasil Belajar Matematika Siswa Kelas VIII SMP Negeri 6 Bontomatene Kepulauan Selayar. Jurnal Matematika Dan Pembelajaran, 3(03), 103116. https://doi.org/10.24252/mapan.2015v3n1a9.

Nasrah, N., \& Muafiah, A. (2020). Analisis Motivasi Belajar Dan Hasil Belajar Daring Mahasiswa Pada Masa Pandemik Covid-19. Riset Pendidikan Dasar, 3(2), 207-213.

Putri, D. T. N., \& Isnani, G. (2019). Pengaruh Minat Dan Motivasi Terhadap Hasil Belajar 
Pada Mata Pelajaran Pengantar Administrasi Perkantoran. Journal of Medives: Journal of Mathematics Education IKIP Veteran Semarang, 3(2). https://doi.org/10.31331/medivesveteran.v3i2.748.

Sa'diyah, S. (2020). Peningkatan motivasi dan hasil belajar sistem gerak melalui model pembelajaran problem based learning. Journal of Curriculum Indonesia, 3(2), 79. https://doi.org/10.46680/jci.v3i2.32.

Sari, K. P., Neviyarni, N., \& Irdamurni, I. (2020). Pengembangan Kreativitas Dan Konsep Diri Anak SD. Jurnal Ilmiah Pendidikan Dasar, 7(1). http://dx.doi.org/10.30659/pendas.7.1.44-50.

Setiadewi, N. P. L., Sujana, I. W., \& Suniasih, N. W. (2019). Kontribusi Konsep Diri Dan Motivasi Berprestasi Terhadap Kompetensi Pengetahuan Ips. Mimbar Ilmu, 24(3), 287. https://doi.org/10.23887/mi.v24i3.21421.

Suminah, S., Gunawan, I., \& Murdiyah, S. (2019). Peningkatan Hasil Belajar dan Motivasi Belajar Siswa melalui Pendekatan Behavior Modification. Ilmu Pendidikan: Jurnal Kajian Teori Dan Praktik Kependidikan, 3(2), 221-230. http://dx.doi.org/10.17977/um027v3i22018p221.

Sunarti, S., Rahmawati, S., \& Wardani, S. (2016). Pengembangan game petualangan "si bolang" sebagai media pembelajaran tematik untuk meningkatkan motivasi dan prestasi belajar siswa kelas V sekolah dasar. Jurnal Cakrawala Pendidikan, 1(1), 5868. https://doi.org/10.21831/cp.v1i1.8365.

Waluya, E. B., Hakim, L., \& Sakti, N. C. (2019). Pengaruh Minat dan Motivasi Terhadap Hasil Belajar Insert Ekonomi Syariah dengan Intervening Kecerdasan Spiritual Pada Mata Pelajaran Ekonomi di Madrasah Aliyah Kota Malang. Jurnal Penelitian, 13(2). http://dx.doi.org/10.21043/jp.v13i2.6001.

Widiastiti, N. L. A., \& Sumantri, M. (2020). Model Quantum Teaching Berbasis Pendidikan Karakter Terhadap Motivasi Belajar IPA. Jurnal Pedagogi Dan Pembelajaran, 3(2), 303. https://doi.org/10.23887/jp2.v3i2.26628.

Yusuf, R. N., Musyadad, V. F., Iskandar, Y. Z., \& Widiawati, D. (2021). Implikasi Asumsi Konsep Diri Dalam Pembelajaran Orang Dewasa. Edukatif: Jurnal Ilmu Pendidikan, 3(4), 1144-1151. https://doi.org/10.31004/edukatif.v3i4.513. 